\title{
CONIDIA PRODUCTION OF Isaria fumosorosea (Hypocreales: Cordycipitaceae) IN ORGANIC SUBSTRATES THROUGH TWO PROPAGATION TECHNIQUES
}

\author{
PRODUÇÃO DE CONÍDIOS DE Isaria fumosorosea (Hypocreales: Cordycipitaceae) \\ EN SUBSTRATOS ORGÂNICOS ATRAVES DE DUAS TÉCNICAS DE PROPAGAÇÃO
}

\author{
Fatima Lizeth GANDARILLA-PACHECO ${ }^{1}$; Myriam ELÍAS-SANTOS ${ }^{1}$; \\ María Elizabeth ALEMÁN-HUERTA ${ }^{1}$; Erick de Jesús de LUNA-SANTILLANA²; \\ Isela QUINTERO-ZAPATA ${ }^{1 *}$
}

1. Universidad Autónoma de Nuevo León, Facultad de Ciencias Biológicas, Instituto de Biotecnología. San Nicolás de los Garza, Nuevo León, México. isela.quinterozp@uanl.edu.mx; 2. Instituto Politécnico Nacional, Centro de Biotecnología Genómica, Laboratorio de Medicina de Conservación. Reynosa, Tamaulipas, México.

\begin{abstract}
In the last decades, the use of entomopathogenic fungi for the control of pest insects has increased globally, however a key step to achieve the successful application of fungal propagules as biocontrol agents depends of various factors, inoculum production being one of the essential stages for these microorganisms to be used in pest management programs. The objective of this study was to evaluate the production of conidia by solid fermentation and biphasic culture in different sporulation matrices for four native isolates and a strain of Isaria fumosorosea that have been shown potential for the control of various insects at the laboratory level. The experimental design was completely randomized, two propagation methods were used with six treatments and ten repetitions per treatment; the data were analyzed using an analysis of variance and the means were compared using the Tukey test $(\mathrm{p} \leq 0.05)$. In the production by solid fermentation the minimum value of $5.30 \times 10^{5}$ conidia $\mathrm{g}^{-1}$ was registered with the pericarp of peanut and the maximum of

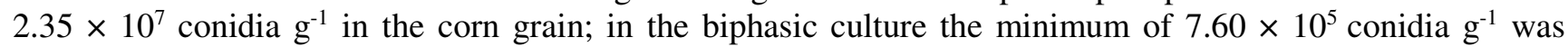
observed in birdseed and the maximum of $2.07 \times 10^{7}$ conidia $\mathrm{g}^{-1}$ in rice. The differences were significant $(\mathrm{p} \leq$ 0.05 ) in the production by method and by substrate, in solid fermentation $6.84 \times 10^{6}$ conidia $^{-1}$ and in biphasic

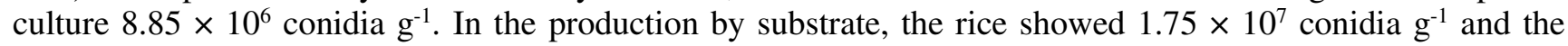

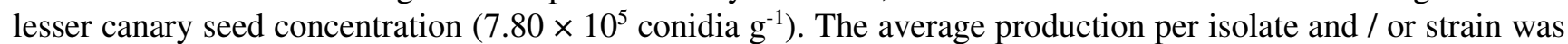
of the order of $10^{6}$ and significant difference was registered $(\mathrm{p} \leq 0.05)$ among the fungi, the isolate HIB-9 showed concentration in average higher in the production $\left(7.90 \times 10^{6}\right.$ conidia $\left.^{-1}\right)$ and the isolated HIB-19 was the least effective, with only $1.08 \times 10^{6}$ conidia $\mathrm{g}^{-1}$. The results obtained show marked differences between the isolates with respect to their capacity to use the different substrates used as propagation media to obtain conidia of I. fumosorosea.
\end{abstract}

KEYWORDS: Entomopathogenic fungi. Two-phase culture. Solid fermentation

\section{INTRODUCTION}

Mexico is a mega diverse country due to its greater biological variety, high number of species, genetic and ecosystem heterogeneity; in this diversity and because of the variety of climates there are many crops of economic importance; however, insects that cause considerable annual losses invade most of them. In the country, there are 29 pests under phytosanitary epidemiological surveillance (SENASICA, 2016). Because of the problem and increase in resistance to chemical insecticides, used for decades to protect against insect pests, the use of environmentally friendly methods has increased. In these strategies is biological control, which involves the action of beneficial organisms on plague organisms. Van Driesche et al. (2007) define biological control as the use of natural enemies, to decrease the population of one or more pests in lower densities, whether temporary or permanent. Natural enemies classified as parasitoids, predators and pathogens, the latter include fungi, bacteria, viruses, nematodes and protozoa; the first two groups called entomophages and the last entomopathogens (BAHENA, 2008). Among the fungi is Isaria fumosorosea an entomopathogen that has a wide range of hosts and an almost worldwide distribution (ZIMMERMANN, 2008); In addition, $I$. fumosorosea is a probable biological control agent for various economically important insect pests of agricultural crops (KIM et al., 2010). Much of the research has focused on the control of the whitefly, 
Bemisia tabaci (MASCARIN et al., 2013). HOY et al. (2010) and STAUDERMAN et al. (2012) evaluated I. fumosorosea as a control agent of Diaphorina citri, the Asian citrus psyllid that spreads the bacterial pathogen and causes yellow dragon disease and known as "Huanglongbing" for its Chinese word. In Brazil, a new product formulated based on conidia of I. fumosorosea that showed activity on nymphs and adults of $D$. citri is being registered (D'ALESSANDRO et al., 2016). According to De Faria;Wraight (2007), I. fumosorosea used as an active ingredient in seven different mycoinsecticides and mycoacaricides in the world, but the initial stages of development of a mycoinsecticide begin with a collection of fungal isolates and the detection of virulence to the target pest. The development of a product requires showing the viability of large-scale production, for which a production system that produces conidia in sufficient quantities for experimental use is necessary and, in addition, they are of consistent quality and compatible with the formulation and equipment. Selected for the application (JENKINS et al., 1998). To improve growth and sporulation of entomopathogenic fungi such as $B$. bassiana, $M$. anisopliae and $I$. fumosorosea nutritional studies were carried out (GRABOWSKI-OCAMPOS et al., 2005; VILLALBA et al., 2009; MASCARIN et al., 2015), but in I. fumosorosea its ability to grow and produce conidia in multiple sources of carbon and nitrogen is a factor that allows its mass production to be relatively inexpensive (CLIQUET; JACKSON, 1999).

The techniques or production methods of conidia most used are solid fermentation, biphasic culture and liquid or submerged culture. With solid fermentation in solid substrates fungi, form conidia from aerial hyphae and this class of spores are more resistant to drying and their shelf life is greater than spores produced in submerged culture (ASSAFTORRES et al., 2002). An alternative to solid fermentation is the biphasic culture, in the initial inoculum it has produced in liquid culture and transferred to a solid substrate to stimulate the production of conidia. This technique was developed to improve industrial production, shorten incubation times and increase conidia production and quality (ALVES; PEREIRA, 1998). In both techniques, a solid phase is required, which would be the most important because the infective propagules of the fungus will develop in it. For this purpose, the most common substrates are grains of rice, corn, wheat or sorghum, and agroindustrial residues such as fruit peels, stubble, etc. Four native isolates and a collection strain of I. fumosorosea that showed potential for the management of Anastrepha ludens Loew (GANDARILLA-PACHECO et al., 2012) and Diaphorina citri Kuwayama (GANDARILLA-PACHECO et al., 2013ab) were selected to study its ability to produce conidia by solid fermentation and biphasic culture using rice grain (Oryza sativa L.) grain and corn cob (Zea mays L.), barley grain (Hordeum vulgare L.), birdseed (Phalaris canariensis L .) and peanut pericarp (Arachis hypogaea L.) as substrates.

The objective of this study was to evaluate the production of conidia by solid fermentation and biphasic culture in different sporulation matrices for four native isolates and a strain of Isaria fumosorosea that have been shown potential for the control of various insects at the laboratory level.

\section{MATERIALS AND METHODS}

\section{Microorganisms}

The I. fumosorosea isolates obtained from the laboratory collection L6 of the Biotechnological Institute, Faculty of Biologic Science-Universidad Autónoma de Nuevo León (FCB-UANL). For their preservation, cryogenic vials with $1 \mathrm{~mL}$ of glycerol at $10 \% \mathrm{v} / \mathrm{v}$ used, stored at $-80{ }^{\circ} \mathrm{C}$. The native isolates correspond to keys HIB-9, HIB-19, HIB32 , HIB-33 and the strain with key Pfr-612 of $I$. fumosorosea.

\section{Inoculum for solid fermentation}

Fungi stored in a cryogenic state, were thawed at $25^{\circ} \mathrm{C}$ and inoculated on potato dextrose agar for 14 to $21 \mathrm{~d}$ at $25 \pm 2^{\circ} \mathrm{C}$. After the incubation time for each fungus, $10 \mathrm{~mL}$ of Tween 80 solution was added at $0.01 \%(\mathrm{v} / \mathrm{v})$, and with a handle a scraping was performed surface in each of the plates with abundant growth to detach the aerial conidia and obtain a concentrated solution. Dilutions were then made to adjust the concentration to $1 \times 10^{6} \mathrm{~mL}^{-1}$ conidia using a Neubauer chamber.

\section{Preculture for two-phase culture}

From the concentration $1 \times 10^{6}$ conidia $\mathrm{mL}^{-1}$ (previous description), $20 \mathrm{~mL}$ were inoculated in $250 \mathrm{~mL}$ baffled Erlenmeyer flasks containing 180 $\mathrm{mL}$ of Sabouraud dextrose broth. The flasks were placed in an orbital shaking incubator under the following conditions; $72 \mathrm{~h}$, at $28^{\circ} \mathrm{C}$ and $250 \mathrm{rpm}$.

\section{Preparation of substrates}

The following substrates were used: rice grain (Oryza sativa L.) grain and corn cob (Zea mays L.), barley grain (Hordeum vulgare L.), 
birdseed (Phalaris canariensis L.) and peanut pericarp (Arachis hypogaea L.). Each of the substrates was immersed in running water at $80^{\circ} \mathrm{C}$ for 30 minutes, then rinsed to the tap and with the help of a strainer the excess water was removed. Subsequently, each substrate placed in a bidistilled water solution containing $0.065 \% \mathrm{v} / \mathrm{v}$ of sodium hypochlorite per liter of water plus $130 \mathrm{ppm}$ of chloramphenicol for 30 minutes. Once the disinfection time had elapsed, they rinsed again with bidistilled water and the excess humidity was removed on sheets of filter paper where they were allowed to stand for 45 minutes. Once the excess moisture was removed, $50 \mathrm{~g}$ of each of the substrates were weighed and placed in high density polyethylene bags with a capacity of $500 \mathrm{~g}$ and sterilized at $121^{\circ} \mathrm{C}, 15 \mathrm{PSI}$ for 20 minutes and left cool for $24 \mathrm{~h}$ before being inoculated.

\section{Inoculation of substrates}

Of the two suspensions, the inoculum for the solid fermentation and the preculture for the biphasic culture, $6 \mathrm{~mL}$ transferred to the bags of each of the substrates, trying to spread them uniformly and then seal hermetically under sterile conditions. Subsequently, they were incubated 14 days at $25 \pm 2{ }^{\circ} \mathrm{C}$ and 12:12 h L: D. The bags were shaken every three days to spread the spores homogeneously on the substrate. At the end of the growth time, the concentration of conidia and the viability percentage were determined.

Substrate productivity evaluation. At 14 days of incubation, the concentration of conidia per gram of substrate of each of the bags was determined. $1 \mathrm{~g}$ of substrate weighed from each of the replicates for each fungus and substrate evaluated and placed in test tubes with Tween 80 solution at $0.01 \%(\mathrm{v} / \mathrm{v})$ and the necessary dilutions were made. To determine the final concentration using a Neubauer camera.

Viability. For both production methods, the viability test performed among the different substrates evaluated over four weeks. $1 \mathrm{~g}$ of each of the substrates added in $16 \times 150 \mathrm{~mm}$ test tubes and shaken with a vortex for 2 minutes to detach the conidia, $100 \mu \mathrm{l}$ of this solution was then taken and plated by simple stria on potato dextrose agar plates and incubated at $20 \pm 2{ }^{\circ} \mathrm{C}$ for 18 hours. Once the incubation time had elapsed, a drop of lactophenol blue added and observed under a microscope at 40x and 100 spores (germinated and ungerminated) counted to quantify the proportion of viable spores according to the criterion of the length of the germ tube. The viability expressed in percentage of germination. The experimental design was completely randomized, two propagation methods (solid fermentation and two-phase culture) were used with six treatments per method (rice grain, corn, barley, birdseed, corn kernel and grain) and ten repetitions per treatment. The results expressed as average values plus the standard error (SE). To verify the normality of the data, the KolmogorovSmirnov test performed, after conversion of the results to its logarithm $\left(\log _{10}\right)$ for the statistical program. With the converted and positive data for the Kolmogorov-Smirnov test, an ANOVA and a Tukey test $(p \leq 0.05)$ performed for the means. For the analysis, the IBM SPSS ${ }^{\circledR}$ v.19 Inc. program was used, New York, USA. The experiments repeated on at least three occasions.

\section{RESULTS AND DISCUSSION}

\section{Production of conidia by solid fermentation}

The production of conidia between the different substrates was from $10^{5}$ to $10^{7}$ conidia $\mathrm{g}^{-1}$ and the production obtained showed no significant difference between the isolates (Table 1), while for the production according to the substrate used if there was a significant difference $(p \leq 0.05)$. The minimum value of $5.30 \times 10^{5}$ conidia $\mathrm{g}^{-1}$ was recorded for the peanut pericarp and the maximum value of $2.35 \times 10^{7}$ conidia $\mathrm{g}^{-1}$ for the corn grain; the grain of rice, corn cob, grain of barley and grain of canary seed presented a production of $1.45 \times 10^{7}$, $8.20 \times 10^{5}, \quad 9.20 \times 10^{5}$ and $8.20 \times 10^{5}$ conidia $\mathrm{g}^{-1}$, respectively (Figure 1). Germination values on average were greater than $70 \%$ at four weeks of storage (Figure 4). 


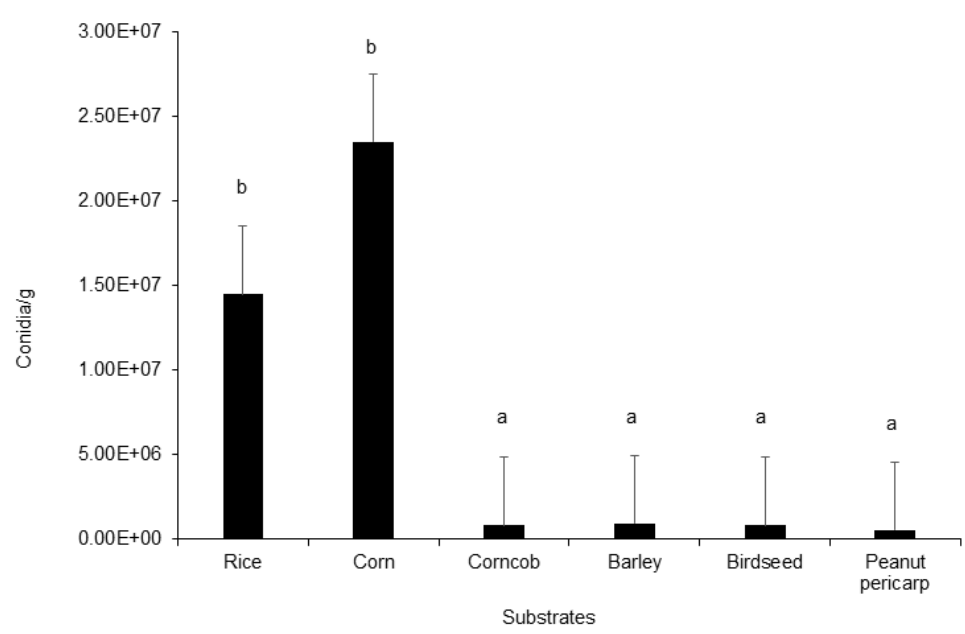

Figure 1. Conidia of I. fumosorosea obtained in different organic substrates by solid fermentation at $14 \mathrm{~d}$ of incubation under laboratory conditions $\left(25 \pm 2{ }^{\circ} \mathrm{C}\right)$. The treatments with different letter are significantly different $(\mathrm{p} \leq 0.05)$.

Table 1. Conidia of I. fumosorosea obtained between the different fungi and organic substrates evaluated by solid fermentation at $14 \mathrm{~d}$ of incubation under laboratory conditions $\left(25 \pm 2{ }^{\circ} \mathrm{C}\right)$.

\begin{tabular}{lcccccc}
\hline & \multicolumn{5}{c}{ Organic substrate $\left(\right.$ conidia $\left.\mathrm{g}^{-1}\right)$} \\
\cline { 2 - 7 } Key isolate & Rice & Corn & Corncob & Barley & Birdseed & Peanut pericarp \\
\cline { 2 - 6 } & & & & & & \\
\hline HIB-9 & $3.05 \times 10^{7}$ & $2.90 \times 10^{7}$ & $3.08 \times 10^{6}$ & $1.72 \times 10^{6}$ & $1.45 \times 10^{6}$ & $7.40 \times 10^{5}$ \\
HIB-19 & $2.18 \times 10^{7}$ & $3.20 \times 10^{7}$ & $4.10 \times 10^{5}$ & $3.60 \times 10^{5}$ & $5.10 \times 10^{4}$ & $1.22 \times 10^{6}$ \\
HIB-32 & $9.00 \times 10^{6}$ & $3.35 \times 10^{7}$ & $2.60 \times 10^{6}$ & $1.64 \times 10^{6}$ & $1.32 \times 10^{6}$ & $7.50 \times 10^{5}$ \\
HIB-33 & $2.55 \times 10^{7}$ & $3.80 \times 10^{7}$ & $4.70 \times 10^{5}$ & $9.80 \times 10^{5}$ & $7.50 \times 10^{5}$ & $1.20 \times 10^{5}$ \\
Pfr-612 & $4.40 \times 10^{6}$ & $6.80 \times 10^{6}$ & $2.50 \times 10^{5}$ & $6.80 \times 10^{5}$ & $4.90 \times 10^{6}$ & $5.20 \times 10^{5}$ \\
Average \pm SE & $1.45 \times 10^{7} \pm 0.15$ & $2.35 \times 10^{7} \pm 0.13$ & $8.20 \times 10^{5} \pm 0.22$ & $9.20 \times 10^{5} \pm 0.12$ & $8.00 \times 10^{5} \pm 0.33$ & $5.20 \times 10^{5} \pm 0.17$ \\
\hline
\end{tabular}

\section{Production of conidia in biphasic culture}

The production of conidia between the different substrates was from $10^{5}$ to $10^{8}{\text { conidia } \mathrm{g}^{-1}}^{-1}$ and the production obtained showed significant differences between the isolates and between the substrates used $(p \leq 0.05)$. The minimum value of $7.60 \times 10^{5}$ conidia $\mathrm{g}^{-1}$ was recorded with the canary grain substrate and the maximum of $2.07 \times 10^{7}$ conidia $\mathrm{g}^{-1}$ for the rice grain (Figure 2); while among the fungi evaluated, the HIB-9 isolate showed the highest average production of conidia per gram $\left(1.52 \times 10^{7}\right)$ and the HIB-19 isolate showed the lowest production with only $8.70 \times 10^{5}$ conidia $\mathrm{g}^{-1}$ (Figure 3). Germination values on average were greater than $70 \%$ at four weeks of storage (Figure 4).

Final comparison of the conidia production of Isaria fumosorosea by method, substrate and fungi evaluated
Regarding the production by method if there was a significant difference between both methods $(p \leq 0.05)$, for solid fermentation the production of conidia of I. fumosorosea was on average $6.84 \times 10^{6}$ conidia $\mathrm{g}^{-1}$, while for the biphasic culture an average of $8.85 \times 10^{6}$ conidia $\mathrm{g}^{-1}$ was reported. Regarding the average production per substrate, there was also a significant difference between them $(\mathrm{p} \leq 0.05)$, the rice grain being the most effective substrate with an average of $1.75 \times 10^{7}$ conidia $\mathrm{g}^{-1}$ and the grain of birdseed the least effective with an average of $7.80 \times$ $10^{5}$ conidia $\mathrm{g}^{-1}$. The average production per isolate and / or strain was of the order of $10^{6}$ and a significant difference was registered $(\mathrm{p} \leq 0.05)$ among the fungi evaluated, with the HIB-9 isolate being the most effective for the production of conidia with an average of $7.90 \times 10^{6}$ conidia $\mathrm{g}^{-1}$ and the isolated HIB-19 the least effective with only $1.08 \times 10^{6}$ conidia $^{-1}$. 


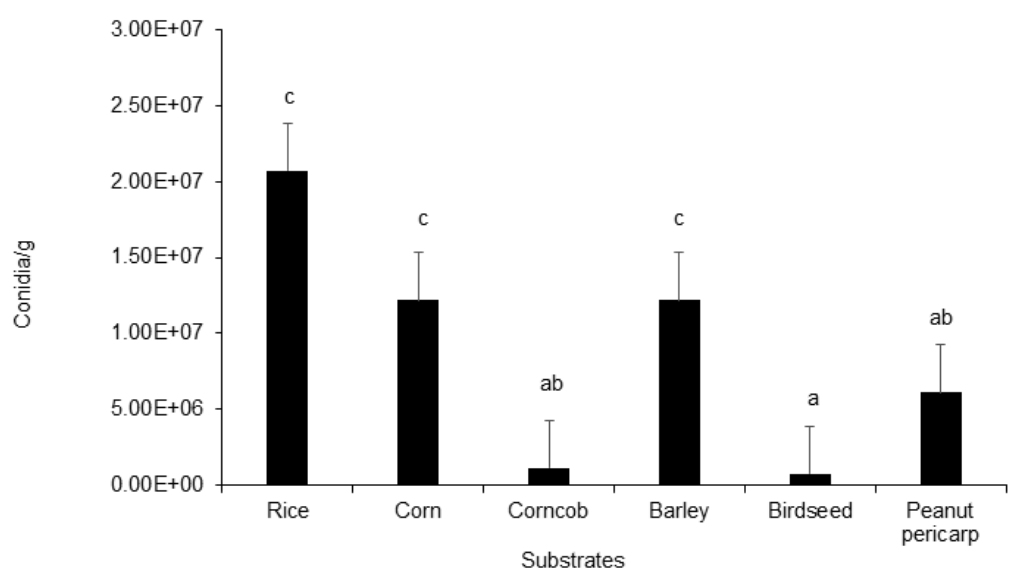

Figure 2. Conidia of I. fumosorosea obtained in different organic substrates by biphasic culture at $14 \mathrm{~d}$ of incubation under laboratory conditions $\left(25 \pm 2{ }^{\circ} \mathrm{C}\right)$. The treatments with different letter are significantly different $(\mathrm{p} \leq 0.05)$.

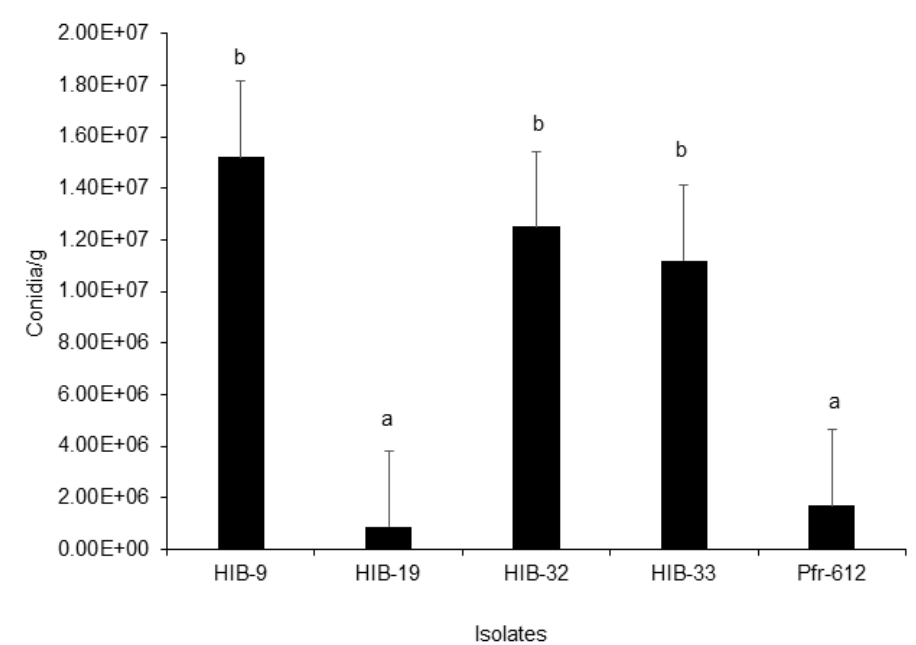

Figure 3. Conidia of I. fumosorosea obtained between the different fungi evaluated by biphasic culture at $14 \mathrm{~d}$ of incubation under laboratory conditions $\left(25 \pm 2{ }^{\circ} \mathrm{C}\right)$. The treatments with different letter are significantly different $(\mathrm{p} \leq 0.05)$.

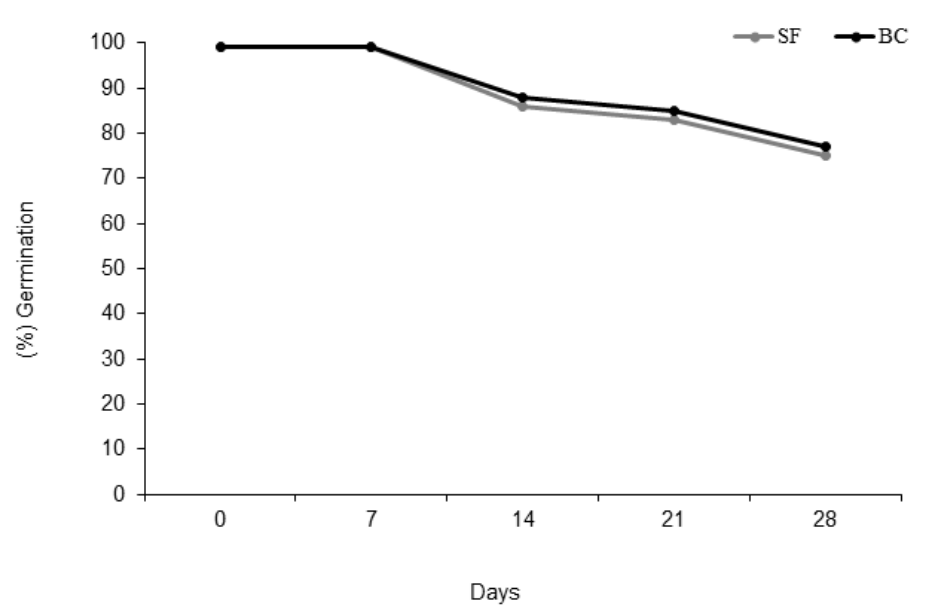

Figure 4. Stability of conidia of I. fumosorosea stored at $4 \pm 2{ }^{\circ} \mathrm{C}$ produced by solid fermentation (SF) and biphasic culture (BC) for four weeks. 
The production of entomopathogenic fungi is based on the massive multiplication of the same and their reproductive structures in a natural substrate as a sporulation matrix, which provides a physical support to the aerial conidia, for this purpose there are different techniques among which stand out the solid fermentation which is considered an artisanal technology in which solid materials and substrates are used, such as corn, beans, potatoes, among others, and biphasic cultivation, which is considered a semi-artisan method that is based on the development of the inoculum in liquid culture agitated for promote rapid growth of the isolate, and thus obtain infective structures in less time that are then used to inoculate a solid phase (VILLALBA et al., 2009).

In this study, the production of conidia of native isolates and a strain of I. fumosorosea was evaluated by means of these two propagation methods using rice grain, corn kernel and grain, barley grain, canary seed and peanut pericarp as substrates. The results showed that for solid fermentation the corn kernel obtained the highest yields $\left(2.35 \times 10^{7}\right.$ conidia $\left.\mathrm{g}^{-1}\right)$ while the peanut pericarp obtained the lowest $\left(5.30 \times 10^{5}\right.$ conidia $g^{-}$ $\left.{ }^{1}\right)$. These results coincide with those reported by Bahdauria et al. (2012) who reported up to $2.33 \times$ $10^{7}$ conidia $\mathrm{g}^{-1}$ for the corn grain, while for the pericarp of peanuts in a study with Trichoderma harzianum they obtained yields of up to $1.80 \times 10^{8}$ spores per gram (MICHEL-ACEVES et al., 2008), far superior to those obtained in this work. Regarding the remaining substrates, the production levels were kept within the range of $10^{5}$ for the cobs, grain of barley and of canary seed and of $10^{7}$ for the grain of rice, which contrasts with the results obtained by Figueroa et al. (2007) who report yields of $6.94 \times 10^{9}$ conidia $^{-1}$ in rice grain and up to 2.19 $\times 10^{10}$ conidia $\mathrm{g}^{-1}$ in barley grain and by Carr et al. (2003) who report $8.00-9.00 \times 10^{8}$ conidia $\mathrm{g}^{-1}$ in husk and rice rind as a substrate with native strains of Paecilomyces fumosoroseus.

Regarding the biphasic culture between the different substrates, the production of conidia per gram was maintained in a range of $10^{5}$ to $10^{8}$ and the production obtained showed significant differences between the isolates and also between the substrates used, registering the minimum of $7.60 \times 10^{5}$ conidia $\mathrm{g}^{-1}$ for the grain of birdseed and the maximum of $2.07 \times 10^{7}$ conidia $\mathrm{g}^{-1}$ for the grain of rice. These results coincide with those reported by Mascarin et al. (2010) for biphasic culture with strains of I. farinosa and I. fumosorosea who report values in a range of $10^{7}$ in different varieties of rice (whole, broken, white) as a substrate and different combinations of liquid media for the pre-inoculum phase. In another study Méndez et al. (2009) carried out the production of Nomuraea rileyi by biphasic culture and reported values of $1.68 \times 10^{10}$ conidia g $^{-1}$, whereas in a study with Lecanicillium lecanii with this same type of culture, values of up to $1.49 \times 10^{9}$ conidia $\mathrm{g}^{-1}$ were obtained using combinations of liquid media obtained from agroindustrial waste and by-products and a solid phase prepared with mixtures of cereals and derivatives (RIBEIROMACHADO et al., 2010).

The heterogeneity of the results obtained in the present study with those reported in the literature may be due to several factors among which the technique used for propagation, the nutritional load of the substrate, as well as the capacity of the same isolate to degrade this substrate can be mentioned and multiply. Mascarin et al. (2010) and Gao ; Liu et al. (2010) mention that an important key aspect to choose a substrate for the production of fungi is to determine its chemical composition with emphasis on its carbon content and the carbon-nitrogen ratio $(\mathrm{C}: \mathrm{N})$, because being products or waste with plant origin their nutrients are considerably variable and will depend on the species and varieties of plants, harvest times as well as the farms and / or plots from which this material comes from the nutrients that may be available and this variation can greatly affect the mushroom production parameters, since there are no standard substrates in the market, however, a nutrient analysis for the different substrates, in order to control these variations, is recommended to ensure the quality of the substrates.

In the present study, a nutritional analysis of each of the substrates used was not performed, however, according to the data reported by the United States Department of Agriculture (USDA 2016), about the nutritional information of the grains of rice, corn and barley that were the ones that obtained the best average yields in terms of the production of conidia per gram for both methods, for the grain of rice they report $79.95 \mathrm{~g}$ of available carbohydrates for only $7.13 \mathrm{~g}$ of protein, for corn $74.26 \mathrm{~g}$ of carbohydrates and $9.42 \mathrm{~g}$ of protein and for barley $73.48 \mathrm{~g}$ of carbohydrates and $12.48 \mathrm{~g}$ of proteins, all these values for every $100 \mathrm{~g}$ of each of these cereals. These values explain in a certain way the results obtained since in comparison with the corn cob, the canary seed and the peanut pericarp, their nutritional composition is more complete at least in these macronutrients, since for example for the grain bird seed each $100 \mathrm{~g}$ only 60.93 are available as carbohydrates (AGRICULTURE AND AGRI-FOOD CANADA, 2016) and for the peanut pericarp and the corn cob their main composition is 
Conidia production of...

based on lignocellulosic compounds such as cellulose, hemicellulose and lignin (RAVERA et al., 2008; CORDOBA et al., 2013), among others, which cannot be exploited in full by fungi such as $I$. fumosorosea because they lack the adequate enzymatic apparatus to do so (DE CAROLINA SÁNCHEZ-PÉREZ et al., 2014) and for other fungi such as Trichoderma harzianum, which agrees with that reported by Michel-Aceves et al. (2008) who mention yields of up to 1.98 and $4.43 \times 10^{8}$ conidia $\mathrm{g}^{-1}$ in pericarp of peanut and corn cob, respectively. On the other hand it is known that enriched media, both in nitrogen and carbon, favor the production of biomass; however, it must be considered that higher mycelial growth does not necessarily result in high conidia production (MÉNDEZ et al., 2009), as mentioned by Moore (1996) that sporulation and mycelial growth can be favored by the presence of monosaccharides such as glucose or fructose, but not all nitrogen sources can favor these processes since amino acids such as asparagine and other ammonia compounds can accumulate during somatic growth by alkalizing the medium and inhibiting the processes of conidiation and growth,
GANDARILLA-PACHECO, F. L. et al.

which agrees with Elósegui (2006) who mentions that to induce the sporulation process in fungi, it is necessary that the carbon source of the culture medium be abundant and the nitrogen content is the growth limiting factor.

\section{CONCLUSIONS}

The difference between isolates and strains of I. fumosorosea, in its ability to produce conidia, depended on the method for propagation and the substrates used to promote it.

This study highlight the fact that the technique of propagation and the substrate chosen to produce conidia of a fungus will be subject in many cases to the physiological characteristics of the same organism and therefore there may be differences between genera and even among isolates of the same genus, for which, for the mass propagation of entomopathogenic fungi, the methodology to be used should be adjusted to each particular case taking into account only the basic aspects reported for that genus or species.

RESUMO: Nas últimas décadas, o uso de fungos entomopatogênicos para o controle de insetospragatem aumentado globalmente, porém um passo fundamental para o sucesso da aplicação de propágulos fúngicos como agentes de biocontrole depende de varios fatores, sendo a produção de inóculo um dos estágios essenciais para esses insetos microorganismos a serem usados em programas de controle de pragas. O objetivo deste trabalho foi avaliar a produção de conídios por meio de fermentação sólida e cultura bifásica em diferentes matrizes de esporulação para quatro isolados nativos e um alinhagem de Isaria fumosorosea que tem demonstrado potencial para o controle de varios insetos em nível laboratorial. O delineamento experimental foi inteiramente casualizado, foram utilizados dois métodos de propagação com seis tratamentos e dezrepetições por tratamento; os dados foraman alisados por meio de análise de variância e as médias comparadas pelo teste de Tukey $(\mathrm{p} \leq 0.05)$. Naprodução por fermentação sólida foi registrado o valor mínimo de $5.30 \times 10^{5}$ conídios $\mathrm{g}^{-1}$ com o pericarpo de amendoim e o máximo de $2.35 \times 10^{7}$ conídios $\mathrm{g}^{-1}$ no grão de milho; na cultura bifásica, o mínimo de $7.60 \times 10^{5}$ conídios $\mathrm{g}^{-1}$ foi observado emsementes de aves e o máximo de $2.07 \times 10^{7}$ conídios g-1 $^{-1} \mathrm{em}^{-1}$ arroz. As diferençasforam significativas $(\mathrm{p} \leq 0.05)$ na produção pelo método e pelo substrato, na fermentação sólida $6.84 \times 10^{6}$ conídios $\mathrm{g}^{-1}$ e na cultura bifásica $8.85 \times 10^{6}$ conídios $\mathrm{g}^{-1}$. Naprodução por substrato, o arroz apresentou $1.75 \times 10^{7}$ conídios $\mathrm{g}^{-1} \mathrm{e}$ a menor concentração de sementes de canário $\left(7.80 \times 10^{5}\right.$ conídios g $\left.{ }^{-1}\right)$. A produção média por isolado e / ou cepa foi da ordem de $10^{6}$ e registrou-se diferença significativa $(\mathrm{p} \leq 0.05)$ entre os fungos, o isolado HIB-9 apresentou concentração em média maior na produção $\left(7.90 \times 10^{6}\right.$ conídios g $^{-1}$ ) e o isolado HIB-19 foi o menos efetivo, com apenas $1.08 \times 10^{6}$ conídios $\mathrm{g}^{-1}$. Os resultados obtidos mostram diferenças marcantes entre os isolados quanto à capacidade de utilização dos diferentes substratos utilizados como meio de propagação para obtenção de conídios de I. fumosorosea.

PALAVRAS-CHAVE: Fungos entomopatogênicos. Cultura bifásica. Fermentação sólida

\section{REFERENCES}

AGRICULTURE AND AGRI-FOOD CANADA. Available online at: http://www.agr.gc.ca (Website accessed: March 28, 2016). 
ALVES, S. B.; PEREIRA, R. M. Produção de fungos entomopatogênicos. In: ALVES S. B. (Ed.). Controle Microbiano de Insetos. Piracicaba, SP: FEALQ, 1998. p. 845-869.

ASAFF-TORRES, A.; REYES-VIDAL, Y.; LÓPEZ Y LÓPEZ, V. E.; DE LA TORRE M. Guerra entre insectos y microorganismos: una estrategia natural para el control de plagas. Avance y Perspectiva, v. 21, p. 291-295,2002.

BAHENA, J. F. 2008. Enemigos naturales de las plagas agrícolas del maíz y otros cultivos. Libro Técnico Núm. 5. SAGARPA - INIFAP. Uruapan, Michoacán, México. 180 p.

BHADAURIA, B. P.; PURI, S.; SINGH, P. K. Mass production of entomopathogenic fungius in agricultural products. The Bioscan, v. 7, n. 2, p. 229-232, 2012.

CARR, A.; ELÓSEGUI O.; BEL PADRÓN, N. Reproducción de dos cepas nativas del hongo entomopatógeno Paecilomycesfumosoroseus (Wize) Brown \& Smith, sobre diferentes soportes líquidos y sólidos. Fitosanidad, v. 7, n. 4, p. 7-11, 2003.

CLIQUET, S.; JACKSON, M. A. Influence of culture conditions on production and freeze-drying tolerance of Paecilomyces fumosoroseus blastospores. Journal of Industrial Microbiology and Biotechnology, v. 23, n. 2, p. 97-102,1999. https://doi.org/10.1038/sj.jim.2900698

CÓRDOBA, J.A.; SALCEDO, E.; RODRÍGUEZ, R; ZAMORA, J. F.; MANRÍQUEZ, R.; CONTRERAS, H.; ROBLEDO, J.; DELGADO, E. Caracterización y valoración química del olote: degradación hidrotérmica bajo condiciones subcríticas. Revista Latinoamericana de Química, v. 41, n. 3, p. 171-175, 2013.

D'ALESSANDRO, C. P., M. R. CONCESCHI E I. DELALIBERA JUNIOR. Um novo bioproduto á base do fungo Isaria fumosorosea para o controle de Diaphorinacitri. Citricultura atual, v. 110, p. 23-24, 2016.

DE CAROLINA SÁNCHEZ-PÉREZ, L.; BARRANCO-FLORIDO, J. E.; RODRÍGUEZ-NAVARRO, S.; CERVANTES-MAYAGOITIA, J. F.; RAMOS-LÓPEZ, M. A. Enzymes of entomopathogenic fungi, advances and insights. Advances in Enzyme Research, v. 2, n. 2, p. 65-76, 2014.

https://doi.org/10.4236/aer.2014.22007

DE FARIA, M. R.; WRAIGHT, S. P. Mycoinsecticides and Mycoacaricides: A comprehensive list with worldwide coverage and international classification of formulation types. Biological Control, v. 43, n. 3, p. 237-256,2007. https://doi.org/10.1016/j.biocontrol.2007.08.001

ELÓSEGUI, O. 2006. Métodos artesanales de producción de bioplaguicidas a partir de hongos entomopatógenos y antagonistas. Instituto de Investigaciones de Sanidad Vegetal (INISAV), Ciudad de La Habana, Cuba. 61p.

FIGUEROA, L. M.; VARELA, A.; CORREDOR, D. Evaluación de sustratos naturales para la propagación masiva del hongo entomopatógeno Paecilomyces fumosoroseus (Deuteromicotina: Hyphomycetes). Revista de Investigación, v. 7, p. 127-131,2007.

GANDARILLA-PACHECO, F. L.; NAVA-GONZÁLEZ, H. D.; ARÉVALO-NIÑO, K.; GALÁN-WONG, L. J.; ELÍAS-SANTOS, M.; QUINTERO-ZAPATA, I. Evaluation of native strains of Isaria fumosorosea (Wize) against Anastrepha ludens (Loew) (Diptera: Tephritidae). Journal of Life Sciences, v. 6, n. 8, p. 957-960, 2012.

GANDARILLA-PACHECO, F. L.; GALÁN- WONG L. J.; LÓPEZ-ARROYO, J. I.; RODRÍGUEZGUERRA, R; QUINTERO-ZAPATA I. Optimization of pathogenicity tests for selection of native strains of entomopathogenic fungi isolated from citrus-growing areas of México on adults of Diaphorina citri Kuwayama (Hemiptera: Liviidae). Florida Entomologist, v. 96, n. 1, p. 187-195,2013a. https://doi.org/10.1653/024.096.0125 
GANDARILLA-PACHECO, F. L.; LÓPEZ-ARROYO, J. I.; GALÁN- WONG, L. J.; QUINTEROZAPATA, I. Patogenicidad de hongos entomopatógenos nativos de la zona citrícola de México sobre ninfas de Diaphorina citri Kuwayama (Hemiptera: Liviidae).Southwestern Entomologist, v. 38, n. 2, p. 325-338, 2013b. https://doi.org/10.3958/059.038.0215

GAO, L.; LIU, X. Effects of carbon concentrations and carbon to nitrogen rations on sporulation of two biological control fungi as determined by different culture methods. Mycopathologia, v. 169, n. 6, p. 475481,2010. https://doi.org/10.1007/s11046-010-9282-9

GRABOWSKI-OCAMPOS, C. J.; ORREGO-FUENTE, A. L.; STAUFFER-BONZON, A. D. Eficiencia de sustratos sobre la esporulación de hongos entomopatógenos Beauveria bassiana, Metarhizium anisopliae yPaecilomyces sp. Investigación Agraria, v.7, n. 1,p. 42-48, 2005.

HOY, M.; RAGHUWINDER, S; ROGERS M. Evaluations of a novel isolate of Isaria fumosorosea for control of the Asian citrus psyllid, Diaphorina citri (Hemiptera: Psyllidae). Florida Entomologist, v. 93, n. 1, p. 2432, 2010. https://doi.org/10.1653/024.093.0103

JENKINS, N. E.; HEVIEFO, G.; LANGEWALD, J.; CHERRYAND, A. J.; LOMER, C. J. Development of mass production technology for aerial conidia for use as mycopesticides. Biocontrol News and Information, v. 19 , n. 1, p. 21-31, 1998.

KIM, J.; JE, Y.; ROH J. Production of thermotolerant entomopathogenic Isaria fumosorosea SFP-198 conidia in corn-corn oil mixture. Journal of Industrial Microbiology and Biotechnology, v. 37, n. 4, p. 419423,2010. https://doi.org/10.1007/s10295-010-0692-y

MÉNDEZ, A.; DEL POZO, E.; GARCÍA, E. I. Producción masiva de Nomuraea rileyi (Farlow) Samson mediante una alternativa de cultivo bifásico. Revista Protección Vegetal, v. 24, n. 3, p. 156-161, 2009.

MICHEL-ACEVES, A. C.; OTERO-SÁNCHEZ, M. A.; MARTÍNEZ-ROJERO, R. D.; RODRÍGUEZMORÁN, N.L.; ARIZA-FLORES, R.; BARRIOS-AYALA, A. Producción masiva de Trichoderma harzianum Rifai en diferentes sustratos orgánicos. Revista Chapingo Serie Horticultura, v. 14, n. 2, p. 185-191,2008. https://doi.org/10.5154/r.rchsh.2005.09.036

MOORE, E. Fundamentals of the fungi. Prentice Hall, New Jersey, USA. 1996. 574 p.

MASCARIN, G. M.; BATISTA-ALVES, S.; BIAGGIONI-LOPES, R. Culture media selection for mass production of Isariafumosorosea and Isariafarinosa. Brazilian Archives of Biology and Technology, v. 53, n. 4, p. 753-761, 2010. https://doi.org/10.1590/S1516-89132010000400002

MASCARIN, G. M.; KOBORI, N. N.; QUINTELA, E. D.; DELALIBERA JR., E. I. The virulence of entomopathogenic fungi against Bemisia tabaci biotype B (Hemiptera:Aleyrodidae) and their conidial production using solid substrate fermentation. Biological Control, v. 66, n. 3, p. 209-218, 2013. https://doi.org/10.1016/j.biocontrol.2013.05.001

MASCARIN, G. M.; JACKSON, M. A.; KOBORI, N. N.; BEHLE, R. W.; JÚNIOR, I. D. Liquid culture fermentation for rapid production of desiccation tolerant blastospores of Beauveria bassiana and Isaria fumosorosea strains. Journal of Invertebrate Pathology, v. 127, p. 11-20, 2015.

https://doi.org/10.1016/j.jip.2014.12.001

RAVERA, C., C. BETTERA, M. A. FERNÁNDEZ, E. ESTIVE Y H. PIÑEDA.2008. Aprovechamiento de los residuos agrícolas. Procesamiento de la caja del maní, su conversión biológica y productos. Memoria del I Simposio Iberoamericano de Ingeniería de Residuos, Castellón, España. Available online at: http://www.redisa.uji.es/artSim2008/tratamiento/A22.pdf. (Website accessed: April 5, 2016). 
RIBEIRO-MACHADO, A. C.; MONTEIRO, A. C.; BELASCO DE ALMEIDA, A. M.; ESPAGNOLIGERALDO MARTINS, M. I. Production technology for entomopathogenic fungus using a biphasic culture system. Pesquisa Agropecuaria Brasileña, v. 45, n. 10, p. 1157-1163, 2010. https://doi.org/10.1590/S0100204X2010001000015

National Service of Health, Safety and Agri-Food Quality (SENASICA). Available online at: http://www.senasica.gob.mx (Website accessed: November 3, 2016).

STAUDERMAN, K.; AVERY, P.; ARISTIZÁBAL, L.; ARTHURS, S. Evaluation of Isaria fumosorosea (Hypocreales: Cordycipitaceae) for control of the Asian citrus psyllid, Diaphorina citri (Hemiptera: Psyllidae). Biocontrol Science and Technology, v. 22, n. 7, p. 747-761,2012.

https://doi.org/10.1080/09583157.2012.686599

ZIMMERMAN, G. The entomopathogenic fungi Isaria farinosa (formerly Paecilomyces farinosa) and the Isaria fumosorosea species complex (formerly Paecilomyces fumosoroseus): biology, ecology, and use in biological control. Biocontrol Science and Technology, v. 18, n. 9, p. 865-901, 2008.

https://doi.org/10.1080/09583150802471812

United States Department of Agriculture Agricultural Research Service (USDA) Food Composition Databases. Available online at: http://ndb.nal.usda.gov/ndb/search/list) (Website accessed: April 3, 2016).

VAN DRIESCHE, R. G., M. S. HODDLE, T. D. CENTER. 2007. Control de plagas y malezas por enemigos naturales. Center USDA, US Forest Service, Forest Health Technology Enterprise Team, Washington, pp: 3-46.

VILLALBA, M. P. L.; GRILLO-RAVELO, H.; CUPULL, R. Producción de esporas de Beauveria bassiana (Bálsamo) Vuillemin sobre polvos de arroz, sorgo y maíz. Centro Agrícola, v. 36, n. 4, p. 25-32, 2009. 